\title{
Bridging the Informatics Gap between School and University with the InfoSukces Contest
}

\author{
Taras PANSKYI ${ }^{1}$, Ewa KORZENIEWSKA ${ }^{2}$ \\ ${ }^{1}$ Institute of Applied Computer Science, Lodz University of Technology \\ 90-537, Lodz, Poland \\ ${ }^{2}$ Institute of Electrical Engineering Systems, Lodz University of Technology \\ 90-924, Lodz, Poland \\ e-mail:tpanski@kis.p.lodz.pl,ewa.korzeniewska@p.lodz.pl
}

Received: October 2020

\begin{abstract}
In Poland, talent development is organized mainly outside or alongside the educational system. A large number of privately funded informatics contests and extra-curricular talent development programs for highly motivated students are available. However, traditional competitions also exist including national informatics Olympiads and competitions mainly supported by the Ministry of Education. In particular, we stimulate interest in informatics by organizing the annual nationwide InfoSukces contest. This contest was organized for the first time in 2015 when informatics education in Poland was experiencing difficulties recruiting new students, who were in growing demand on the labor market. The aim of the contest is now to make students aware that the jobs of the future require problem-solving, digital skills, and creative thinking, all of which can be taught through informatics. The contest also provides a platform for a unique series of activities, the goal of which is to support partnerships and knowledge flow between schools and universities. This article provides a case study of the final stage of the InfoSukces contest, which involves the participants developing a "work of art" in the Scratch programming environment. It also presents the holistic method for quantitative evaluation of the students' creative visual-based programming projects.
\end{abstract}

Keywords: informatics education, informatics contest, holistic approach, Polish talents.

\section{Introduction}

Talented young people should be nurtured with care and interest. They are crucial for social development and economic growth both locally and nationally. Proper identification of talent at an early stage helps young people to fulfill their potential, and make a greater contribution in their professional life. Informatics skills as directional skills are manifested as a special interest in informatics issues, and the ability to acquire skills and use them to creatively solve informatics problems (Stachera et al., 2014). As with other technical subjects, they are also closely related to mathematical skills. 
An extensive system for identifying talented students and providing them with extra opportunities in informatics is already in place in primary education (Diks et al., 2018; Sysło, 2011). This is partly provided at school, in the form of accelerated possibilities and extra lessons. There are also some schools that have the main purpose of supporting gifted students. Examples include the Warsaw network of 195 schools with a current Certificate of the President of the Capital City of Warsaw WARS and SAWA, which implement tailored school programs to support informatics talent (Kozak and Jaromin, 2016).

Government educational policy is interwoven with the policies of the Ministry of National Education, and it determines the provision for gifted and talented children. In order to be able to fully implement this provision, in the rapidly developing digital world, clearly defined regulations concerning all matters of educating gifted students had to be created. The general rules were set in the Education Law (in Polish: Prawo oświatowe) of December 14, 2016 (Kancelaria Sejmu, 2016). Appropriate parental advocacy and communication with teachers and schools, are extremely important to develop a shared understanding of the specific strengths and challenges of each talented student. Therefore, the Education Law has been complemented by provisions that were directly related to the issues of educating gifted students and regulate the principles of work organization and the conditions for supporting talented youth (Ministerstwo Edukacji Narodowej [MEN], 2013; 2019; 2020a; 2020b). At present, the Polish government is willing to spend large amounts of money on education in general and on primary education in particular. Many schemes for excellent students in informatics are already in place in primary education and the government strongly supports their further development.

Talent development is organized mainly outside or alongside the Polish school educational system. A large number of informatics competitions, contests, summer schools, Olympiads, and extra-curricular talent development programs for highly motivated students are available, mostly sponsored through private foundations (Wolfensberger, 2015). However, a number of traditional competitions exist, including national Olympiads or competitions for young researchers and engineers, which are mainly supported by the Ministry of Education. One such event aimed at stimulating interest in informatics and training students to study programming is the annual nationwide InfoSukces contest (Konkurs informatyczny InfoSukces, 2020). This contest was conceived in 2015 when informatics education in Poland was experiencing difficulties recruiting new students and training informatics specialists, who were in increasing demand on the labor market. This contest is a one-of-a-kind set of activities aimed at connecting universities with schools to better prepare talented students for future careers in informatics-related fields.

The purpose of this article is to clarify the impact of the InfoSukces contest on learning informatics of primary/secondary school talented students. It addresses the following research questions:

- Do primary/secondary school students participating in the InfoSukces contest have different learning outcomes compared to average Polish students learning without the informatics contest challenges?

- Do the talented finalists of the InfoSukces contest have the approximate equivalent informatics learning outcomes compared to Polish university first-year candidates? 


\section{Polish School Educational System}

The education system in Poland is governed by Acts of Parliament and adopted ministerial regulations, in particular, by the Minister of National Education, who is responsible for general education, vocational education, and skills, as well as the Minister of Science and Higher Education. Regulations of the Minister of National Education specify detailed arrangements in the structure of the school education system, management and funding, admissions, assessment and certification, and establish, in particular, outline timetables for public schools. A major reform in the primary school education system was initiated in the school year 2017/2018 and in high schools in the school year 2019/2020, to strengthen general education as the basis for further personal development of students (Kolanowska, 2018). The reform will be completed in the school year 2022/2023 and in the technical schools in the school year 2023/2024. Compulsory education in Poland is divided into one-year pre-primary education for 6-year-old children; full-time education for young people aged 7 to $15 / 16$ years; education for young people aged 15/16 to 18 years. Since the $2017 / 2018$, the school system at the primary level consists of the 8 -year single structure primary education for students aged 7-15/16. Moreover, primary education is divided into two ISCED levels: early school education (grades I-III) and subject-based primary education (grades IV to VIII). According to the Polish National Curriculum, all young people are required to learn informatics (in Poland "informatics" is equivalent to "computer science") in primary schools.

In the Polish education system, there is a spiral model of achieving the goals and tasks set out in the new Core Curriculum, which favors the repetition of teaching material to reinforce and sophisticate it each time the students revisit subjects matter many times extending its scope and progressing from simplistic to complicated ideas and applications. (Sysło, 2019). In grades I-III informatics is taught for at least average an hour per week. Students learn the informal meaning of selected notions related to informatics, often in the form of play. Key skills to be developed by informatics provide school students with foundational concepts in informatics by integrating basic skills in technology with simple ideas about algorithmic thinking. Key skills to be developed by informatics include the use of linear order repeating actions (e.g. arranging patterns, pictures, texts, events in a logical sequence); the use of technology resources (e.g., puzzles, logical thinking programs, writing tools, digital cameras, drawing tools) for problemsolving, communication, and illustration of thoughts, ideas, and stories; the use of the online resources (e.g., online discussions, Web environments) to participate in collaborative problem-solving activities; competencies such as creativity, innovativeness and entrepreneurship; intellectual curiosity and motivation to learn. Students know how to describe internal and external parts of computing devices; are familiar with real-world cybersecurity problems; are able to organize and present collected data visually to highlight relationships and support a claim; could create simple programs in block-based visual environments that include sequences, events, loops, and conditionals.

The new curriculum provides for the minimum of one hour weekly allocated to informatics classes in grades IV-VIII. The minimum number of hours may be increased at each headmaster's discretion and may be allocated to activities developing students' interests 
in informatics. The curriculum contains a section on algorithmic thinking, problem-solving using computers, computational thinking, and game-based learning. Students could design projects that combine hardware and software components to collect data; model the role of protocols in transmitting data across networks; collect data using information and communication technology (ICT) tools and transform the data to make it more reliable, use flowcharts to address complex algorithms; design programs that combine control structures, including nested loops and compound conditionals, decompose problems into parts to facilitate the implementation of programs (Panskyi et al., 2019). Moreover, students develop critical and logical thinking, as well as reasoning, argumentation and deduction skills; creative solving of problems in various areas while using purposefully ICT-based methods and tools, including programming; solving problems with the use of mediation techniques.

Gurbiel et al. (2005) show the educational pre-reform (before transformation) of the Polish education system and its main objectives. Sysło (2014) has carefully described the history of informatics education in Polish schools in the years 1965-1990. Wiśniewski and Zahorska (2020) show the history of the challenges of education reforms in Poland from 1999 to the present in the context of social changes. Besides the methodological issue of the new curriculum (Sysło and Kwiatkowska, 2015), research literature reveals that school informatics in Poland is still confronted with a number of problems. Nonetheless, Poland remains one of the few countries where informatics remains compulsory for students from K1 to K11 curriculum standards.

Firstly, the initial task of the authorities is to configure a school network in accordance with the requirements of the new curriculum. The new Core Curriculum has become more demanding with the progressive changes in education policies and government support for informatics as an academic goal in Poland. However, there is still a difference between the implementation of competences intended by the Core Curriculum and the actual educational aspects of school activities. The main three organizations have a major impact on the functioning of schools: local authorities (material teaching conditions), Education Boards (supervising and evaluation regulatory aspects), and school principals (coordination of the learning process at school). According to (Wiśniewski and Zahorska, 2020), the new core curriculum was introduced without proper infrastructure, textbooks, and manuals. Teachers universally perceive poor guidelines of the new curriculum established standard requirements to be achieved. As a result, teachers have not fully received support, with new textbooks accompanied by manuals with new pedagogic methodology, didactic tools, lesson plans, and teaching aids.

Secondly, the ICT, computational and programming skills, teachers require, can be inferred from the competencies students need to develop throughout their schooling to enable them to "adapt flexibly to a rapidly changing and highly interconnected world" (Tabach and Trgalová, 2019). The new Core Curriculum emphasizes a school autonomy where teachers have an opportunity to promote innovative approaches to teaching informatics and to experiment with new learning methods. Therefore, the Polish educational system is now focusing on the development of policies for integration teaching practices according to the new curriculum. These policies require a comprehensive system aimed at teachers properly integrate ICT, creative programming, algorithmic thinking, game- 
based and problem-based learning into their teaching practice and mediate its use and impact. Therefore, training, workshops, and courses are essential and urgent to provide teachers with opportunities to learn about effective, appropriate, and intentional use of ICT in their teaching practice (Ihmeideh and Al-Maadadi, 2018; Alayyar and Fisser, 2019). Moreover, in addition to strictly technical skills related to the use of ICT equipment, it is extremely important to shape awareness among teachers about the desirability of using technology in school teaching informatics. The current state is assessed as random activities both in terms of content (lack of certification, low technical level and low quality of training, courses, workshops) and organizationally (a large supply of unverified courses, a multitude of activities without the possibility of comparing training effects). In addition, preparing teachers for professional activity in the digital world of students to achieve their didactic goals requires that the system of their improvement of new methodological approaches and training content. Teachers require further clarification to better understand the new curriculum. If the curriculum refers to "creative problem solving", then methodical preparation of teachers for work and assessment of the student in terms of his creativity is necessary. Creativity has many dimensions (e.g. originality, flexibility, diligence, etc.) and varieties (e.g. verbal and non-verbal creativity). This means that current activities should be accompanied by an in-depth analysis of the strictly educational objectives and in a broader sense: transformational and modernization ones. The tools for their implementation (especially projects raising teachers' methodological and digital competences) should be strengthened (Głomb et al., 2019).

Last but not least, teachers slowly adapt to technological and pedagogical changes and, as a result, teaching methods are still based on traditional epistemologies. According to Bates (2015), teachers should use traditional technologies in combination with digital ICT. However, teachers have not understood still that personal development is crucial for teaching informatics, since teachers play a pivotal role in education, their perception of the innovation will strongly influence their students' thinking.

Currently, teachers limit the perception of the real state of affairs (the digital consciousness deficit). To a large extent, they identify computerization only with a simple conversion of forms of activity from analogue to digital. An example of "pseudoinformatization" thinking is the usage of multimedia boards by some teachers. They mainly serve as a replacement for a classic blackboard or screen for displaying video materials, although their functionalities allow for much wider usage. Such interactive boards are extremely useful for activation of the whole class especially in grades I-III. However, teachers will only be able to use them successfully in the classroom once they are confident in handling it. And this requires time and an appropriate training system - not one-time, several hours, but several months or even years well-thought-out and professionally conducted, best suited to a specific subject of study. A large number of teachers are still reluctant or ineffective to use digital educational tools that support the process of informatics teaching. From the students' perspective, the teacher who turns on the PowerPoint presentation on the wall, rewrites the rigid formulas from the textbook and uses the historic programming language, can be perceived as equally archaic, as if he read from a roll of papyrus or writing on wax tablets. Moreover, the role of teachers is not only to educate themselves and develop their professional knowledge but also to 
promote and integrate innovations in informatics teaching and prepare their students for lifelong learning.

The primary need for a digital transformation of the school, as well as overall participation in the information society life, results not only from the educational goals posed by the Polish education system but also from the need to integrate and harmonize the everyday students' world. The continuation of the current model of support for raising the level of methodical and digital competences of informatics teachers will only result in widening the visible gap between the world of their concepts and experiences, and the digital habitat of students. Informatics disruption at school changes our culture, creates new, previously unknown communication channels, revolutionizes our civilization environment. This means the evolution of a new hybrid model of school education, where new digital competences and their level will be fine-tuned to current personal and professional challenges of teachers and students.

The differences between the described above educational requirements prepared and introduced parts of the educational reform and the way of conducting classes, in consequence, determine the educational skills of students and discrepancies between their preparation and the expectations of universities.

\section{Acceleration of Talented Students}

Bringing informatics into primary schools as a formal track in the curriculum was a crucial step. However, it is necessary also to support extra-curricular activities, which can help to introduce students to informatics. Government-supported or -coordinated programs provide such opportunities as well as financial support to help gifted students to grow their talent. The largest existing programs are Regional Operational Programmes (see Table 1).

Students with a strong interest in informatics require special treatment and educational pathways adapted to their individual needs. Recently, the Council of Ministers adopted a resolution on establishing a multi-annual programme entitled "Informatics Talent Development Programme for 2019-2029” (Program Rozwoju Talentów Informatycznych na lata 2019-2029, 2020), submitted by the Minister of Digitization. This programme will support the development of young people with above-average abilities in the areas of algorithmics, programming and computer game design.

Although the Ministry of National Education has focused on talent support programmes in primary education, it has also started to focus on providing financial support for talented secondary school students. The Scholarship of the Prime Minister and the Scholarship of the Minister of National Education are awarded to students who received a distinction, obtaining the highest average in the school or showing special informatics skills. There are also various informatics competitions and contests for primary and secondary school students, such as the nationwide Capture The Flag '153 + 1' (Konkurs $C T F, 2020)$, curatorial informatics competitions Olimpiad in Informatics for secondary school students (Olimpiada Informatyczna, 2020) and Junior Olimpiad in Informatics for primary school students (Olimpiada Informatyczna Juniorów, 2020), LOGIA (Konkursy Informatyczne Logia, 2020), Bebras (Międzynarodowy Konkurs Informaty- 
Table 1

The biggest Regional Operational Programmes, including an EU contribution and domestic sources, supporting talented students in informatics

Name of the project

Scholarship assistance programmes for talented students (Programy pomocy stypendialnej dla uczniów zdolnych, 2020).

2 Scholarship program for gifted students - the best investment in people (Program stypendialny dla uczniów szczególnie uzdolnionych - najlepsza inwestycja w człowieka, 2020).

3 Lubelska Forge of Talents 2019-2021 (Lubelska kuźnia talentów 2019-2021, 2020).

4 We invest in talents (Inwestujemy $w$ talenty $-I V$ edycja, 2020).

5 Małopolska Talents (Małopolskie Talenty, 2020).

6 Algorithmics and Programming Championship (Mistrzostwa w Algorytmice i Programowaniu, 2020)

7 The Informatics Championship Center (Centrum Mistrzostwa Informatycznego, 2020)
Aim of the project

to strengthen educational opportunities and the level of self-fulfillment of 530 particularly gifted students in the field of informatics.

to develop talents, increase motivation to continue learning and develop education in 641 students through scholarship assistance. Support will be directed towards students achieving high results in the field of informatics.

to strengthen educational opportunities and the level of self-development of 790 especially gifted students in the field of informatics through scholarships.

scholarship assistance granted to students with special talents in mathematical and informatics subjects.

to create conditions for the development of talents in mathematics, informatics, and supra-objective social competences in primary school students.

to activate secondary schools students in terms of developing the most advanced informatics skills, such as algorithmic thinking, problem-based learning and programming.

to strengthen Polish informatics education aimed at educating over 12 thousand of particularly gifted primary school students with the involvement of the best technical universities in the country.

czny Bóbr, 2020), Algorithmic skirmishes (Potyczki Algorytmiczne, 2020), HackJunior (HackJunior 2020) etc. These competitions and contests are organized and/or supported by the Ministry of National Education under the patronage of private foundations or non-governmental organizations. There are a number of informatics competitions and contests that are organized by the governmental institutions (schools, HEIs, Education Development Centers) and fully or partially sponsored by private foundations such as the Master IT (Master IT, 2020), Interactive IT product (Interaktywny produkt IT, 2020), Informatics Quadrathlon (Quadrathlon Informatyczny, 2020), etc. Finally, there are a bunch of initiatives that are organized and sponsored in most by private organizations: Programming Academy (Konkurs - Pix Programming Challenge, 2020), Instalogik (InstaLogik, 2020), The MindCloud Polish Championship (Mistrzostwa Polski MindCloud, 2020), ADB Brain Wars (ADB Brain Wars, 2020) or Hack Heroes (Hack Heroes, 2020) under the patronage of the Ministry of Digital Affairs, etc.

Participation in competitions and contests facilitates contact with other students with similar informatics interests or skills, and the creation of peer groups in which outstanding students do not feel alienated. Competitions can play an invaluable role in identifying talented students and providing informatics education. Generally, they require knowledge and skills that go far beyond what is taught at school. Achievements in competitions 
and contests might also be rewarded with financial support (scholarships) or other assistance with opportunities to experience internships at the best informatics companies in the world. However, most of the competitions follow the still ongoing paradigm of narrow specialization: Regional Operational Programmes mostly increase students' digital literacy with the usage of ICT, while the rest of the informatics contests are based only on programming, algorithmics, and logic. Only the InfoSukces contest could offer wider opportunities that go far beyond the scope of informatics including creative and computational thinking. Furthermore, the natural destination for the most talented students is in Higher Education, and the unique nationwide informatics contest InfoSukces provides a kind of bridge between the university and schools. The aim of the InfoSukces initiative is to provide greater opportunity and support for students with special informatics skills.

\section{InfoSukces Contest}

The InfoSukces contest is run by the Faculty of Electrical Engineering, Electronics, Computer Science and Automatics at Lodz University of Technology. In 2015-2020, nearly 700 students from all over Poland took part. The scope and form of the contest are designed to familiarize students with possibilities for further informatics education at Lodz University of Technology, and for future careers in professions related to informatics and its applications. The contest is divided between two age groups: 14-15 years (basic level) and 16-18 years (advanced level). Students from all over Poland can participate in the contest. They can subscribe using a dedicated form available on an Internet platform. Table 2 shows the numbers of participants by age and gender over the years.

The contest consists of 3 stages:

Stage I. The student develops and submits an original project related to a topic using modern technologies. For example, the topic for 2019 was "5G Technology". The task involved preparing a presentation or game describing $5 \mathrm{G}$ technology. The project could be made using any informatics technique. The completed work should be sent within a specified period. Students who obtained $50 \%$ of the maximum number of points in the first stage qualify for the next stage.

Stage II. In the second stage, the students take a test consisting of 20 closed questions at the location of the organizer under exam conditions. The scope of the test for primary school students covers basic informatics with elements of logical thinking. All the tasks for secondary students are based on the current set of examination requirements set out in the Matura examination book for computer science. Students who obtain $70 \%$ of the maximum number of points during Stage II or a maximum of the 10 best students will qualify for the final. The example tasks for both basic and advanced levels are shown in Appendix A and B.

Stage III (final). The final stage takes place at the location of the organizer. The final contest task is to solve a problem using the Scratch visual programming environment. At the end of the third stage, the Contest Commission will select the winners, i.e. participants who have obtained $70 \%$ of the possible points in the third stage. 
Table 2

Numbers of participants in the InfoSukces contest $2015-2020$ by gender and age

\begin{tabular}{|c|c|c|c|c|c|}
\hline \multirow[t]{2}{*}{ Year } & \multirow[t]{2}{*}{$\begin{array}{l}\text { Age group } \\
\text { (years) }\end{array}$} & \multicolumn{2}{|c|}{$\begin{array}{l}\text { Overall number of participants } \\
\text { (stage I) }\end{array}$} & \multicolumn{2}{|c|}{$\begin{array}{l}\text { Overall number of participants } \\
\text { (stage III) }\end{array}$} \\
\hline & & Boys & $\overline{\text { Girls }}$ & Boys & $\overline{\text { Girls }}$ \\
\hline \multirow[t]{3}{*}{2015} & $14-15$ & 28 & 3 & 5 & - \\
\hline & $16-18$ & 22 & 2 & 4 & 1 \\
\hline & Total & 50 & 5 & 9 & 1 \\
\hline \multirow[t]{3}{*}{2016} & $14-15$ & 60 & 10 & 7 & 3 \\
\hline & $16-18$ & 44 & 7 & 11 & 1 \\
\hline & Total & 104 & 17 & 18 & 4 \\
\hline \multirow[t]{3}{*}{2017} & $14-15$ & 44 & 6 & 3 & 1 \\
\hline & $16-18$ & 42 & 10 & 14 & 2 \\
\hline & Total & 86 & 16 & 17 & 3 \\
\hline \multirow[t]{3}{*}{2018} & $14-15$ & 36 & 11 & 7 & 4 \\
\hline & $16-18$ & 40 & 3 & 15 & 1 \\
\hline & Total & 76 & 14 & 22 & 5 \\
\hline \multirow[t]{3}{*}{2019} & $14-15$ & 25 & 6 & 10 & 1 \\
\hline & $16-18$ & 48 & 2 & 23 & - \\
\hline & Total & 73 & 8 & 33 & 1 \\
\hline \multirow[t]{3}{*}{2020} & $14-15$ & 27 & 7 & 12 & 2 \\
\hline & $16-18$ & 40 & 13 & 18 & 1 \\
\hline & Total & 67 & 20 & 30 & 3 \\
\hline \multicolumn{2}{|c|}{ Overall total } & 456 & 80 & 129 & 17 \\
\hline
\end{tabular}

The winners and finalists of the contest at the basic level will receive additional credit during the selection procedure for secondary schools. These points are awarded by the School Superintendent. For the winners of the contest at the secondary level, a "golden ticket" certificate is envisaged enabling students to enter any faculty at the Lodz University of Technology without passing the classification procedure. Passing the Matura exam is the only condition for using this certificate.

\subsection{InfoSukces Statistics}

The study sample consists of 682 primary and secondary school students aged 14 to 18 , from K9 to K12 using the international grade system. The contest is aimed at all interested students from public/private primary and secondary schools in Poland in the years 2015-2020. Interested students could use an online form for registration purposes. Online registration is tied directly to the university domain and contest web page. The registration relies on submitting basic information which includes participant's first and last name, age, and email. The distribution of InfoSukces participants according to the place of residence is presented in Table 3. 
Table 3

The distribution (by provinces) of InfoSukces participants

\begin{tabular}{lcc}
\hline Polish provinces & Age group 14-15 (\%) & Age group 16-18 (\%) \\
\hline Lodz & 18.18 & 16.33 \\
Kuyavian-Pomeranian & 9.09 & 16.33 \\
Masovian & 19.45 & 16.33 \\
Opole & 9.09 & 6.12 \\
Podlaskie & 4.55 & 2.04 \\
Silesian & 15.97 & 7.36 \\
Greater Poland & 18.18 & 10.20 \\
Subcarpathian & 2.27 & 18.37 \\
Pomeranian & 2.27 & 6.12 \\
The rest & $<1.00$ & $<1.00$ \\
\hline
\end{tabular}

We collected data from this sample during six contest events: in 2015, 55 participants qualified for the contest; in 2016, 121; 102 in 2017; 90 in 2018, 81 in 2019 and 87 in 2020. The second event in 2016 had the largest number of participants (121); the fewest took part in the first InfoSukces contest (55). The low number of participants in 2015 may be attributed to insufficient marketing and the lack of word-of-mouth recommendations from former participants and their parents.

The participants were divided into two age groups, with a year's gap in between: 14-15 and 16-18. The proportion of participants in the younger age group was the largest $(57.9 \%)$ in 2016 and the smallest (38.3\%) in 2019. Conversely, the maximum and minimum percentages of participants per year in the older age group were the opposite (maximum $61.7 \%$ in 2019 , a minimum of $42.1 \%$ in 2016). With respect to gender, there have been consistently more boys than girls, with $85 \%$ and $15 \%$, respectively. In the first contest (2015) and the fifth event (2019), respectively, 90.9\% and $90.1 \%$ of the participants were boys. On the other hand, there were large numbers of girls in the third and fourth contests, comprising $15.7 \%$ and $15.6 \%$ of the total numbers of participants. The highest percentage of girls participated in the 2020 edition $(20,3 \%)$ of the Infosukces contest.

\subsection{Gender Differences}

Modern society tends to underestimate the girl's contribution to today's digital world and the various fields of creativity and intellectual endeavours. In Poland, girls are vastly underrepresented in the fields whose members cherish brilliance (such as informatics and STEM subjects). In the 2014/2015 academic year, only $12 \%$ of the total number of students in informatics-related fields were girls. In many faculties run by technical colleges in 2019, there are very few girls, e.g. in electrical engineering $(6.7 \%)$, control engineering and robotics $(9.1 \%)$, mechatronics $(9.5 \%)$. There is extensive research on which might be the reasons why girls do not feel attracted to ICT and 
informatics studies or why they do not think about their future careers in these fields. These factors can be included in three categories: lack of appropriate family and teachers support (Sáinz et al., 2012; Stockdale and Keane, 2016), negative professional stereotypes and myths about girls' intellectual abilities in ICT and informatics (Master et al., 2016; Pechtelidis et al., 2015; Cunningham, 2015) and personal attitudes (Kubiatko, 2013; Spanos and Sofos, 2015).

According to Drabowicz (2014) and Notten et al. (2009) boys use computers and the Internet more often for entertainment than for school-related tasks (Tømte and Hatlevik, 2011). However, with respect to the computer and information literacy scale, girls scored higher than boys in most countries (Fraillon et al., 2014, Meelissen et al., 2014). According to Litt (2013) boys reported higher levels of ICT literacy than girls. On the other hand, Kim et al. (2014) and Hatlevik et al., (2015) has shown that girls perform better than boys in ICT-related assessments. Hatlevik and Christophersen (2013) research studies have not found gender differences in ICT literacy. Ardito et al. (2020) revealed gender differences regarding computational thinking. Finally, Malik and Coldwell-Neilson (2020) and (Mladenović et al., 2020) have not revealed gender differences in informatics, on the other hand Funke et al. (2015) pointed out there is an observable gender difference in informatics in school settings.

According to Smith (2010), boys are better in areas of math that involve logical and analytical thinking. Panskyi et al. (2019) argued that girls learn informatics through meticulous and systematic scrutiny of the material in a precise and detailed manner, while boys tend to have a greater tendency toward high programming abstraction and design. Lee et al. (2017) examined gender issues in computational thinking and creativity, and they found no significant gender difference. Girls had greater creativity levels than boys, whereas boys maintained higher levels of academic interest than girls. On the other hand, Kong et al. (2018) found that girls were significantly less interested in programming than boys. Boston and Cimpian (2018) emphasized that providing role models for girls was the key to success in STEM subjects.

Nevertheless, according to Alkhadrawi (2015), despite the fact that no significant differences in the intellectual performance of boys and girls in ICT and informatics assessments have been reported, a closer examination of the carrier choice reveals certain persistent differences in preferences regarding STEM subjects. In Poland, the main reasons for the gender gap are still related to the lack of appropriate family and teachers' support, negative professional stereotypes and self-efficiency. Common professional stereotypes associate high-level intellectual ability (brilliance, genius, etc.) with boys more than girls. Bedyńska et al. (2019) showed the concept of intellectual helplessness of Polish girls. That concept applies the informational model of learned helplessness to difficulties in the acquisition of new and complex knowledge (algorithms, programming etc.) (Rydzewska et al., 2017).

Even in the last decade in Poland, it was claimed that girls are more emotional and warm, they should present higher results in the science of humanities (e.g. literature, history, art) and/or social (e.g. psychology, pedagogy, knowledge of society). The sight of a girl discussing stubbornly, who has her own opinion, e.g. on the fastest sorting algorithm or the construction of an electric motor, aroused surprise and even resistance 
among teachers. From this point of view, it is told that it does not fit the girl to do something with a screwdriver or a soldering iron and to help to repair the computer. Moreover, in school settings when the informatics assignment is not solvable or a teacher cannot explain the subject matter, such an approach cannot lead to real progress in cognitive processing (Bedyńska et al., 2020). Hence, after the prolonged cognitive mobilization and without any substantial cognitive gain, a cognitive exhaustion phase appears. Finally, a cognitive exhaustion phase could lead to the motivational and emotional dysfunctions in girls' educational development.

To eliminate the influence of these factors, the new mechanism of school achievement should be applied. Moreover, this mechanism should be highly important for teachers and policymakers as it could shape the interest and further girls' motivation to pursue an education in informatics domains.

Recently, in Poland, the result of the good work of policymakers is a systematic increase in the percentage share of girls among students at informatics-related fields. Currently, over 12,000 girls are studying this field in 2019 (12155, which is 814 more than in the $2017 / 2018$ academic year), it is $14.6 \%$ of the total number of students at informaticsrelated fields (Fundacja Edukacyjna Perspektywy, 2019). The growing number of IT specialists is the result of increasing awareness of girls, informatics education, and IT professions. Promotional activities directed at women, which encourage them to take up informatics studies and planning a career in STEM fields play an important role. Among these programs, there is the only one scholarship program in Poland addressed to girls "New technologies for girls" and the largest Polish inspirational program for informatics students - "IT for SHE". The activities of numerous women's groups in IT and STEM fields - such as "Geek Girls Carrots" and "Girls in Tech" are also important for the promotion of IT careers among women.

In the history of the InfoSukces contest (2015-2020), girls represented on average $17.5 \%$ of the total number of participants. The percentage share of girls in the contest is comparable with the share of girls (14.6\% in 2019) among students at informatics-related fields. The dynamics of changes in the number of girls, participants of the contest, indicate a gradual increase in the percentage share from $10 \%$ in 2015 to $30 \%$ in 2020 . In addition, the contest organizer conducts a broad marketing strategy, promotional and motivational activities to encourage new ICT and informatics female enthusiasts. Master et al. (2017) emphasized two types of interest in informatics and ICT-related subjects: situational and individual interest. Situational interest is triggered within an immediate experience and may or may not last over time. Individual interest is a persistent inclination to engage with particular activities over time. InfoSukces organizer provides a wide range of experiences, such as conversations with parents and teachers, inspirational videos and presentations, an invitation of guest speakers - former contestants, to trigger girls' situational interest in informatics and technology. Moreover, the contest organizer helps and suggests teachers how to develop girls' interest from situational to an individual, for example, by offering informatics assignments or to show new opportunities. Once situational interest is triggered with an appropriate motivation strategy, girls have the opportunity to evolve this situational interest into a more durable and strong individual interest (Crowley et al., 2015). 


\subsection{The Final Stage of the Contest}

For the third stage of the InfoSukces contest in 2019, the task set was to prepare the game of Go using the Scratch environment. This traditional Chinese board game, which is also popular in Korea and Japan, has in recent years gained increasing popularity around the world, especially because of the interest of its computer realization. Go is often compared to Chess, due to their similarities as two-player strategic games (Johnson et al., 2016). Go has many rules for specific board states; however, only the basic rules and those relevant to the presented research can be found in Fairbairn (2010) and Bozulich (2001).

The Scratch visual-based programming environment (Kurniawan, 2018; Lye and Koh, 2018) was chosen to ensure equal chances for young people attempting the final task. In Polish schools, there is no single obligatory programming language used during informatics classes. Young people learn different languages (block-based in grades I-VI, text-based in grades VI-VIII), but rarely using Scratch programming environment in higher grades. For this reason, the organizers of the contest decided to use Scratch to implement the final project.

The participants were informed of the evaluation criteria at the start of the final project, so they knew from the very beginning how their work would be assessed. Positions were accorded based on the total number of points awarded by the members of the jury. The submitted works were evaluated independently by five people (jury). Three of these were academic teachers and two representatives of the business sector with an interest in acquiring well-educated engineers to implement informatics projects in the future. The maximum score available for the completed game was 100 points. The following elements were assessed:

Criterion 1. The game meets the requirements specified according to the rules given in the contest task (max. 50 points):

1. Elements have the correct arrangement at the beginning. The drawings provided by the organizer were correctly used for the game (max. 5 points).

2. The laying of individual stones at the intersection of lines works correctly (max. 5 points).

3. A stone cannot be placed in an already occupied space (max. 5 points).

4. The "change" cycle is also implemented, one time there is a black stone and once the white one (max. 5 points).

5. After circling a given color, the stones that are "out of breath" are compacted and automatically removed from the board (max. 20 points)

6. A stone can be placed again in a vacated space (max. 5 points).

7. The game ends according to the above conditions (max. 5 points).

Criterion 2. Game aesthetics and functionality (e.g. arrangement of individual elements) (max. 20 points):

1. The game is aesthetically pleasing - the game elements do not interfere with each other, appropriate colors, fonts, etc. were chosen (max. 5 points). 
2. The game is functional, containing elements such as the start and end, with appropriate messages (max. 5 points).

3. During the game, the number of points scored by each player (color) is indicated on the board and the playing time elapsed for individual players (colors) is indicated (max. 10 points).

Additional criteria (max. 30 points):

An automatic move should be performed by the computer when the organizer's logo is clicked. The correctness (whether the correct, unoccupied intersection is occupied max. 10 points) and effectiveness of this solution (whether the proposed algorithm supports the chance for a "good move" - max. 20 points) will be evaluated.

The jury evaluates the criteria of the third stage every year. The distribution of partial points for fulfilling the above-mentioned criteria is analyzed. It is expected that this distribution will be a normal one. In the absence of such dependence, the jury changes the evaluation criterion.

Fig. 1 shows a screenshot of the game that received the highest number of points in the third stage of the InfoSukces contest in 2019. The jury awarded the work at a total of 86 points of a possible 100 . The breakdown of points for each individual criteria was as follows: criterion $1-40$ points; criterion $2-16$ points; criterion $3-30$ points. The work performed an algorithm for the automatic removal of stones (criterion 1.5), although it did not work correctly every time the program was started. In addition, the playing time was not shown (criterion 2.3). The second place was taken by a project which scored 83 points. Third place was taken by a project with 80 points.

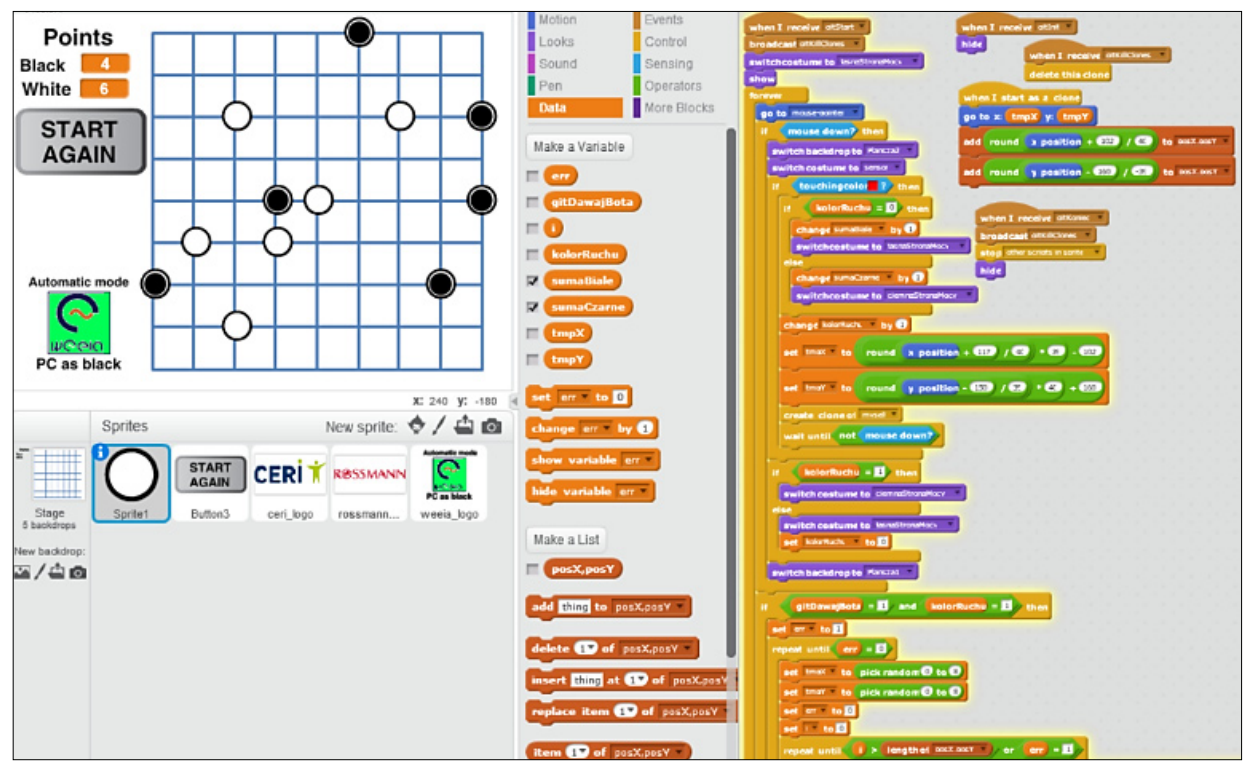

Fig. 1. Screenshot of the winning project in the 2019 contest (Go game). 


\subsection{Statistical Analysis}

During the InfoSukces contest, the talented primary/secondary school students are able to gain qualities of the analyst (analysis of ideas and experience, discover open problems and challenges), researcher (understanding of the operation, performance, interaction of systems), designer (development of alternative and innovative solutions within given limitations and constraints), computing engineer (simulation, problem-solving using most appropriate software environment), effective communicator (both oral and written, in native and foreign technical language), open-minded person (the ability to think outside national frame, long-life education), and even more.

As described above, the contest consists of three stages, each of them has different requirements for participants. Entering the contest requires the students to be prepared in many fields. The requirements of each stage relate to the extensive students' knowledge with a strong interdisciplinary background that can be applied to every domain of knowledge as a coherent core of common concepts such as logical and algorithmicthinking, programming, etc., essential for solving problems and developing informatics skills. Preparation for the contest requires participants to acquire knowledge in many areas regardless of the quality of the classes taught at school and the content provided by the subject teacher. Besides, it should be noticed that in many cases students who want to enter the contest mobilizes their teachers to conduct classes innovatively with a focus on problem-solving, using modern teaching methods such as problem-based learning, game-based learning, flipped classroom or open schooling. This partially answers the first question, however, in the case of the second research question, the additional comprehensive analysis should be applied.

The quantitative analysis and measuring informatics learning outcomes in a way that enables us to make comparisons across primary/secondary school students (aged 14 to 17 years) and university candidates (aged 18/19 years) is difficult. Maturity exam (matura) is the major form of external examination to ensure the comparability of learning outcomes. The maturity certificate is obtained upon passing the maturity exam in a general or technical secondary school. Every secondary school student who planning to study at the university must pass three mandatory Matura examinations. Matura is taken at the end of secondary education, by young people aged 18/19 years to enter the institutions of higher education. Moreover, the informatics Matura examination could not be chosen as a mandatory examination, so secondary school students took it as an additional examination at an advanced level. As a result, nowadays in Poland, there are no standardized tests, exams or criteria that try to measure informatics learning outcomes in primary/secondary school settings at the university domain. One of the possible approaches to learn from overlapping but disparate university informatics criteria is to put them on a consistent scale, pool them together across the pipeline of primary/ secondary school students' talented skills, and then linked them in a common measurement system to maximize coverage across the country.

Therefore, we created a set of contest criteria which are closely related to the learning outcomes that students must comprehend in specific informatics subjects. Thereafter, we imposed these criteria on the learning outcomes obtained by the finalists of the 
InfoSukces contest and compared how close the finalists were to university candidates in their knowledge acquisition, mastery of informatics skills, or development of their key abilities. This set of criteria is based on an outcomes-based approach that makes our expectations more transparent to both the primary/secondary school talented students and university candidates. Moreover, this approach starts with a specification of what the primary/secondary student will be expected to achieve by the end of the InfoSukces contest thereby confirming or refuting the feasibility of such an informatics contest as a bridge between school and university. A set of criteria form the basis for the assessment framework including quality assurance checks and benchmarking for the validation process.

The validation data set consists of 15 criteria and their short names (see Table 4), where each covers the students' educational outcomes of specific informatics subjects at university.

Table 4

A set of validation criteria

Item/Criterion

Short name

The student is able to formulate the concept of visualization of physical and technical problems CR1 and present the methods of their implementation with the help of the acquired knowledge and practical skills with the use of appropriate tools.

The student knows the basics of computer graphics, understands the way of defining various types CR2 of graphic scene objects.

The student has extensive knowledge of development trends and current directions of informatics CR3 design and related fields.

The student can integrate knowledge from various fields of science - including mathematics, CR4 physics, chemistry, and others, and apply a systemic approach that also takes into account nontechnical aspects.

The student is able to acquire knowledge and develop skills thanks to a creative participation in CR5 the process of solving a problem in an innovative way.

The student has a basic knowledge of computer structure, personal computer software and CR6 computational complexity, and is able to explain computer operation and basic tasks of operating systems.

The student can write numbers in natural systems: binary and hexadecimal, as well as convert CR7 their value to the decimal system.

The student can analyse and design simple algorithms, formulate a verbal description of an CR8 algorithm, construct algorithms in the form of flowcharts.

The student knows and understands issues in the field of programming, implementation and CR9 testing of programs and programming styles.

The student has the ability to apply Boolean Algebra.

The student can define and apply: simple computer concepts, variables, arrays, arithmetic and CR11 conditional expressions, control instructions, functions.

The student can design, implement and evaluate a project system that meets the imposed CR12 requirements, at the same time selecting techniques appropriate for this purpose.

The student is able to analyse a complex problem and propose its solutions, showing creativity CR13 in combining knowledge in the field of computer science and other, specific to a given problem, disciplines.

The student chooses the right strategy for developing a computer game. 
Since the readers may require a more convincing explanation dedicated to the first research question, the authors additionally performed the qualitative analysis. The analysis is based on the comparison of the informatics learning outcomes the primary/secondary school students should achieve and the outcomes of the InfoSukces finalists in reference to the set of validation criteria. After analyzing the Polish National informatics curriculum applicable in the didactic process in the primary/secondary school, the requirements of CR14-CR15 are issues that young people must develop additionally when entering the InfoSukces contest. The requirements of CR1-CR5 and CR9-CR11 are covered in the National informatics curriculum, while CR12-CR13 are the result of the project-based learning. The other criteria are fully in line with the Polish National informatics primary/secondary school curriculum.

The research was transversal, i.e. it covered a focus group at a particular moment. The set of criteria is divided into three main parts: the CR1-CR5 are dedicated to the learning outcomes the participants should achieve after the $I^{\text {st }}$ stage of the InfoSukces contest, the CR6-CR10 - after the $I^{\text {nd }}$ stage and CR6-CR10 - after the IIIrd stage respectively. It is obvious that the finalists of the InfoSukces contest should achieve all the CR1-CR15 learning outcomes. The academic teachers have the opportunity to keep track with young people gifted in creative programming and problem-solving outcomes overall contest stages. Moreover, they could evaluate the finalists' learning outcomes by a set of criteria and mark one of four options in Likert's scale, ranging from "Certainly achieve" to "Certainly not achieve". Thereby, we are able to make comparisons in rather small deviations or significant differences in learning outcomes of primary/ secondary school students and university candidates.

The first step in the quantitative conclusion consists of the descriptive statistics for the validation criteria towards learning outcomes in informatics. Table 5 includes the short names for each criterion, the average values of the scores reported as mean with standard deviation, and Cronbach's Alpha. The academic teachers evaluate the learning outcomes achieved by the 146 finalists of the InfoSukces contest during the 2015-2020 year.

The academic teachers overall reported positive average scores in all CR1-CR15 criteria towards finalists' informatics learning outcomes. Moreover, they all received the above-average scores ranked from 2.06 to 3.10 except the CR 15 with a $1.58 \pm 0.13$ average score. The maximum average score has been reported in CR1 (3.1 \pm 0.16$)$ followed by CR2 $(2.8 \pm 0.25)$ and CR12 (2.72 \pm 0.23$)$. The minimum average score has been reported in CR15, which is dedicated to informatics learning outcomes in the field of artificial intelligence. Analysis of internal consistency showed that the Cronbach's alpha was 0.79 for a set of 15 criteria, indicating good scale reliability. As it is seen from the statistic for the InfoSukces contest, the overall picture is therefore rather bright for Polish talented primary/secondary school students. According to the informatics matura examination report in 2020 (Centralna Komisja Egzaminacyjna, 2020), the average of matura result was $29 \%$. The InfoSukces contest statistics shows that the average is $79 \%$ of the achieved informatics learning outcomes set by the authors and described in Table 5. It should be noted that the authors' evaluation system of the CR1-CR15 differs from one's from the matura examination, however, considering the 
Table 5

Descriptive statistics

\begin{tabular}{llllll}
\hline Item/Criterion & Min & Max & Average & Std. Deviation & Cronbach's alpha \\
\hline CR1 & 1 & 4 & 3.10 & 0.16 & \\
CR2 & 1 & 4 & 2.80 & 0.25 & \\
CR3 & 1 & 4 & 2.06 & 0.17 & \\
CR4 & 1 & 4 & 2.32 & 0.22 & \\
CR5 & 1 & 4 & 2.22 & 0.21 & \\
CR6 & 1 & 4 & 2.36 & 0.26 & \\
CR7 & 1 & 4 & 2.52 & 0.24 & \\
CR8 & 1 & 4 & 2.28 & 0.26 & \\
CR9 & 1 & 4 & 2.64 & 0.25 & \\
CR10 & 1 & 4 & 2.14 & 0.18 & \\
CR11 & 1 & 4 & 2.36 & 0.29 & \\
CR12 & 1 & 4 & 2.72 & 0.23 & \\
CR13 & 1 & 4 & 2.48 & 0.22 & \\
CR14 & 1 & 4 & 2.18 & 0.20 & \\
CR15 & 1 & 4 & 1.58 & 0.13 & \\
Total 15 criteria & & & & & \\
\hline
\end{tabular}

cohesion and coverage of presented CR1-CR15 criteria with the required informatics learning outcomes set by the Polish National curriculum such a statement can be admitted in evidence. This means, that primary/secondary school students, the finalists of the InfoSukces contest are able to achieve the informatics learning outcomes that go far beyond the scope of the Polish National informatics curriculum which in turn is indisputable proof and answer to the first research question. Moreover, in its overwhelming majority, the finalists of the InfoSukces contest achieve the proper informatics learning outcomes commensurate with the university candidates and answer to the second research question.

The work presented here has some limitations. We focused on measuring the informatics learning outcomes in a way that enables us to make comparisons across primary/ secondary school students and university candidates. Therefore, the biggest limitation is a set of 15 criteria that corresponds to the particular learning outcome in specific informatics subjects at Lodz University of Technology. The main task of academic teachers was to create a core set of benchmarking criteria for the validation process. Albeit, the number of criteria is purely heuristic and may be increased or decreased in a reasonable amount. Secondly, a set of criteria outlines of what the primary/secondary student will be expected to achieve by the end of the InfoSukces constest without taking into account the difficulty of achieving certain learning outcomes. Obviously that not all criteria can be equated since some learning outcomes require more time and informatics skills from primary/secondary students while others are achieved easily by default. Fig. 2 shows the detected outliers during the LOF (local outlier factors) procedure of outlier detection. 


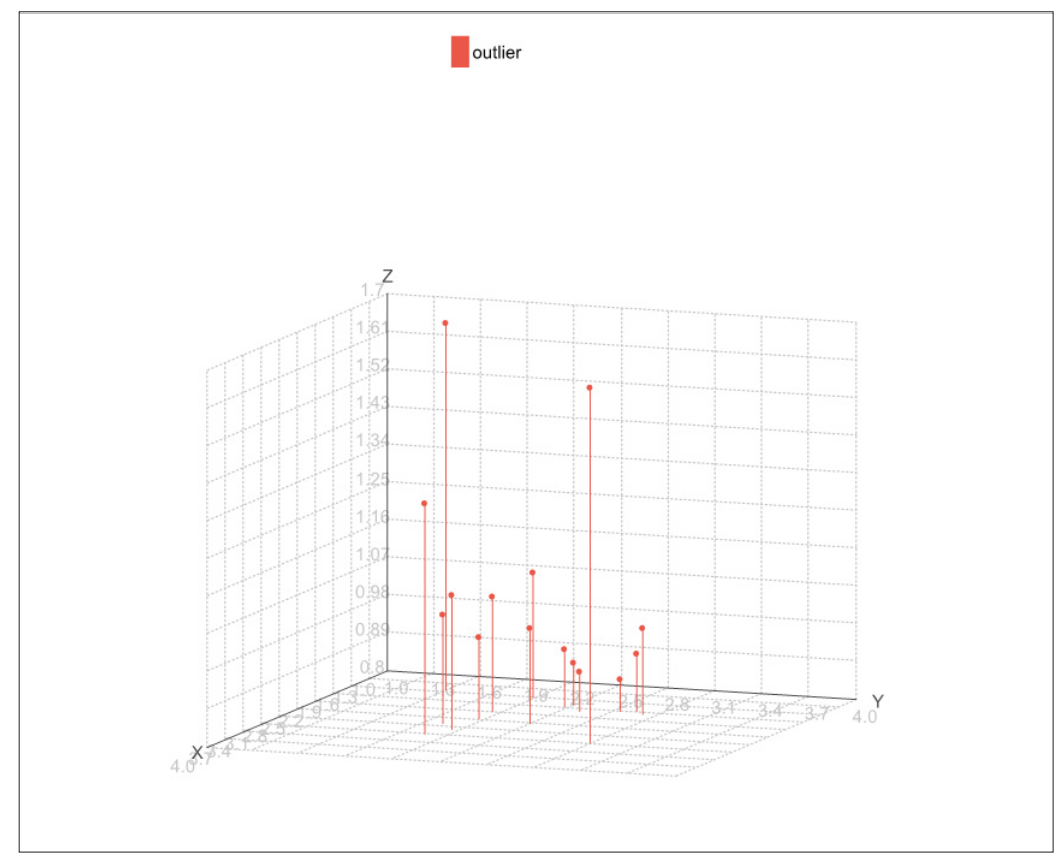

Fig. 2. Local outlier factor for anomaly detection across a set of benchmark criteria. Axis X corresponds to the average scores in all CR1-CR15 criteria towards the girls-finalists' informatics learning outcomes, axis $\mathrm{Y}$ - the average scores in all CR1-CR15 criteria towards the boys-finalists' informatics learning outcomes, respectively. Axis $Z$ shows the vertical sticks whose height corresponds to the detected outliers.

The LOF is based on a concept of a local density, where locality is given by the $k$ nearest neighbours, whose Euclidean distance is used to estimate the density. According to the LOF method the minimal points lower bound and minimal points upper bound parameters are set to 10 and 20 respectively. By comparing the local density of an object to the local densities of its neighbours, one can identify regions of similar density and points that have a substantially lower density than their neighbours. Fig. 2 shows the three clear outliers (three highest peaks) that correspond to the CR8 (left), CR15 (middle) and CR1 (right). These criteria should be re-evaluated and changed for compliance at further research.

Another limitation may be a relatively low number of primary/secondary school finalist, i.e.146 students. Yet, even though we should be cautious in the interpretation of these findings due to a small sample size, they provide us with relative confidence about the veracity of discovered arguments. 


\section{Conclusions}

Talented students need to be challenged to develop. Taking part in contests is one way for them to be confronted with a range of tasks which stretch their abilities and creativity, and prepare them to take on new challenges in the future. In Poland, informatics contests are growing in popularity. One such contest is InfoSukces, which has been run annually since 2015. InfoSukces tests a range of fundamental informatics concepts and skills needed by students in various disciplinary fields, which provide new and meaningful ways to interpret the world and to approach problems. In the first stage of the contest, students are encouraged to apply their digital creativity and abstract thinking. In the second stage, the participants are expected to show foundational skills in logical, computational and algorithmic thinking. In the final stage, each student should be able to model problems and acquire specific programming skills through game-based and problem-based learning.

The pool of contestants for such contests is stable with a slight downward trend in the recent 2020 year, and this puts added pressure on their organizers. According to Forišek (2010), the contestants are also improving in their skills each year. As a consequence, the tasks which are set must be made harder and harder, to enable the top contestants to be distinguished. Nevertheless, as shown in Table 1 the number of participants who reached stage III of the InfoSukces contest has increased each year (this tendency has not been observed last year due to the COVID-19 pandemic). This suggests that talented youngsters are developing not only their areas of particular skills and interests but also their overall levels of informatics knowledge.

It should be noted that boys currently show the most intense interest in IT. The field of science and computing is still male-dominated, and women are in a minority in informatics-related careers. The older cohorts of competitors included fewer girls. This is in line with statistics relating to the number of women studying IT. According to the "Women in IT" report (Fundacja Carrots, 2018), there are only 3 or 4 women per 10 male programmers.

While there are currently significant differences by gender in terms of participation in scientific and informatics contests, growing evidence suggests that a number of external factors influence girls' opportunities to participate in informatics activities and may predict continued involvement in fields such as programming, robotics and automatics. Efforts by educators, researchers and government organizations seem to have had a positive effect on making informatics attractive to girls. The upward trend in female interest in informatics is evident at the national level as well. Our study suggests that encouraging greater levels of participation in programming contests such as InfoSukces, particularly among girls, may lead to increased motivation and greater chances to learn informatics.

Attention should be paid to the didactic value of competitions and contests in general. The fact of being laureate or finalist, even receiving a distinction or diploma, causes joy and great appreciation. Many careers and further life choices had their beginnings at school and participating in some contests. The research done among primary/secondary school students showed that praising and positive motivation is the most motivating 
factor for further work. Preparing students for competitions and contests is primarily based on their abilities and interests. There is no doubt that it is worth and possible to shape the students' interests. It is more difficult to determine how to do it, which factors, methods and forms of impact are the most effective. According to the authors of the article, the InfoSukces initiative as a contest developing informatics skills in various aspects is a holistic contest supporting the development of students in broadly understood informatics. Students are mobilized to work systematically on their development, which is a particularly important component of pedagogical activities that dynamize the development of their interests and talents, which is particularly important in the context of students with higher informatics expectations.

The InfoSukces contest is a relatively new one compared with, for example, the Bebras or the Polish Olympiad in Informatics with a rich history of international competitions. The entire contest is an initiative of the ambitious academic environment, which would like to prepare students to become comfortable taking on tasks outside of their expertise, persevering and remaining innovative; to act as a predictor of productivity and creative potential to overcome the 21 st-century global society's most pressing challenges. Nowadays, the opportunities for the Infosukces contest to create new paradigms of competition-based informatics learning will depend largely on a shared academic vision and strategic planning to meet not only the current needs but also have sufficient capacity to meet future requirements - establishing effective infrastructure for Polish talented students.

\section{References}

ADB Brain Wars (2020). http: //www . adb-brain-wars .com/

Alayyar G., Fisser P. (2019). Human and Blended Support to Assist Learning About ICT Integration in (Preservice) Teacher Design Teams. In: Pieters J., Voogt J., Pareja Roblin N. (eds) Collaborative Curriculum Design for Sustainable Innovation and Teacher Learning. Springer, Cham.

Alkhadrawi, A. (2015). Gender differences in math and science choices and preferences. The University of Toledo.

Bates, T. (2015). Teaching in a digital age. BCcampus, BC Open Textbook Project, Victoria.

Bedyńska, S., Krejtz, I., Rycielski, P., Sedek, G. (2020). Stereotype Threat As An Antecedent To Domain Identification And Achievement In Language Arts In Boys: A Cross-Sectional Study. Social Psychology Of Education, 23, 755-771.

Bedyńska, S., Krejtz, I., Sedek, G. (2019). Chronic Stereotype Threat And Mathematical Achievement In Age Cohorts Of Secondary School Girls: Mediational Role Of Working Memory, And Intellectual Helplessness. Social Psychology Of Education, 22 (2), 321-335.

Boston, J.S., Cimpian, A. (2018). How Do We Encourage Gifted Girls To Pursue And Succeed In Science And Engineering?. Gifted Child Today, 41 (4), 196-207.

Bozulich, R. (2001). The Go player's almanac. Kiseido Publishing Company, Tokyo.

Centralna Komisja Egzaminacyjna. (2020). Sprawozdanie za rok 2020 (p. 19). Warsaw: Centralna Komisja Egzaminacyjna. Retrieved from https://cke.gov.pl/images/_EGZAMIN_MATURALNY_OD_2015/ Informacje_o_wynikach/2020/sprawozdanie/EM_Informatyka_sprawozdanie.pdf

Centrum Mistrzostwa Informatycznego (2020). https://cmi.edu.pl/.

Crowley, K., Barron, B.J., Knutson, K., Martin, C. (2015). Interest and the development of pathways to science. In: Renninger K.A., Nieswandt M., Hidi S. (eds) Interest in Mathematics and Science Learning. Washington DC: AERA, 297-313.

Cunningham, B. (2015). Gender Differences in Science, Technology, Engineering, and Mathematics (STEM) Interest, Credits Earned and NAEP Performance in the 12th Grade. NCES. 
Diks, K., Idziaszek, T., Łącki, J., Radoszewski, J. (2018). Looking for a Challenge?. Wydawnictwo Naukowe PWN, Warsaw.

Drabowicz, T. (2014). Gender and Digital Usage Inequality Among Adolescents: A Comparative Study Of 39 Countries. Computers \& Education, 74, 98-111.

Fairbairn, J. (2010). Invitation to go. Dover Publications, Mineola, N.Y.

Forišek, M. (2010). The Difficulty of Programming Contests Increases. Teaching Fundamentals Concepts of Informatics (ISSEP 2010).

Fraillon, J., Ainley, J., Schulz, W., Friedman T., Gebhardt, E. (2014). Preparing for life in a digital age: The IEA International Computer and Information Literacy Study International Report. International Association for the Evaluation of Educational Achievement (IEA), Amsterdam.

Fundacja Edukacyjna Perspektywy (2019). Kobiety na Politechnikach. Warszawa.

Fundacja Carrots (2018). Kobiety w IT. Analiza sytuacji kobiet w branży IT w Polsce. Warszawa.

Funke, A., Berges, M., Mühling, A. and Hubwieser, P. (2015). Gender differences in programming: Research results and teachers'perception. In Proceedings of the 15th Koli Calling Conference on Computer Education Research, ACM, Finland.

Głomb, K., Jakubowski M., Krawczyk, A., Kulisiewicz, T., Nowakowski, Z., Złotnicki, A., Gajderowicz, T. (2019). Kompetencje przyszłości w czasach cyfrowej dysrupcji. Stowarzyszenie „Miasta w Internecie, Fundacja Naukowa Evidence Institute.

Gurbiel, E., Hardt-Olejniczak, G., Kolczyk, E., Krupicka, H., Syslo, M. (2005). Informatics and ICT in Polish Education System. From Computer Literacy To Informatics Fundamentals (ISSEP 2005).

Hack Heroes (2020). http: //hackheroes . pl/index . html

Hatlevik, O. E., Christophersen, K-A. (2013). Digital Competence At The Beginning Of Upper Secondary School: Identifying Factors Explaining Digital Inclusion. Computers \& Education, 63, $240-247$.

Hatlevik, O.E., Guðmundsdóttir, G.B., Loi, M. (2015). Digital Diversity Among Upper Secondary Students: A Multilevel Analysis Of The Relationship Between Cultural Capital, Self-Efficacy, Strategic Use Of Information And Digital Competence. Computers \& Education, 81, 345-353.

Ihmeideh, F., Al-Maadadi, F. (2018). Towards Improving Kindergarten Teachers' Practices Regarding The Integration Of ICT Into Early Years Settings. The Asia-Pacific Education Researcher, 27 (1), 65-78.

Interaktywny produkt IT (2020). http://www . informatyka. am. szczecin. pl/ipit

Instalogik (2020). https://instalogik.pl/

Inwestujemy w talenty - IV edycja (2020). https : //mapadotacji.gov.pl/projekty/784783/

Johnson, C., Barford, L. Dascalu, S.M., Harris, F.C. (2016). CUDA Implementation Of Computer Go Game Tree Search. Advances In Intelligent Systems And Computing, 339-350.

Kancelaria Sejmu (2016). Dz.U.2017.59. Ustawa z dnia 14 grudnia 2016 r.-Prawo pświatowe (p. 83).

Kim, H-S., Kil, H-J., Shin, A. (2014). An Analysis Of Variables Affecting The ICT Literacy Level Of Korean Elementary School Students. Computers \& Education, 77, 29-38.

Kolanowska, E. (2018). The system of education in Poland. Foundation for the Development of the Education System, Warsaw.

Kong, S-C., Chiu, M.M., Lai, M. (2018). A Study Of Primary School Students' Interest, Collaboration Attitude, And Programming Empowerment In Computational Thinking Education. Computers \& Education, $127,178-189$.

Konkurs CTF (2020). https : //konkurs153plus1.firebaseapp.com/index

Konkurs informatyczny InfoSukces (2020). http://www. weeia.p.lodz.pl/konkursy/konkurs-informatyczny-infosukces-2/

Konkurs - Pix Programming Challenge (2020). https : //pixchallenge.org/konkurs /

Konkursy Informatyczne Logia (2020). http: //logia . oeiizk . waw . pl/\#! /

Kozak, K., Jaromin, E. (2016). Warszawski system wspierania uzdolnionych. Biuro Edukacji Urzędu Miasta, Warszawa.

Kubiatko, M. (2013). The comparison of different age groups on the attitudes toward and the use of ICT. Educational Sciences: Theory and Practice, 13(2), 1263-1272.

Kurniawan, A. (2018). Visual Programming with Scratch. Raspbian OS Programming with the Raspberry Pi.

Lee, J., Jung, Y., Park, H.K. (2017). Gender Differences In Computational Thinking, Creativity, And Academic Interest On Elementary SW Education. Korean Association Of Information Education, 21(4), 381-391.

Litt, E. (2013). Measuring users' internet skills: A review of past assessments and a look toward the future. New Media \& Society, 15(4), 612-630.

Lubelska kuźnia talentów 2019-2021 (2020). https://mapadotacji.gov.pl/projekty/839301/

Lye, S., Koh, J. (2018). Case Studies of Elementary Children's Engagement in Computational Thinking 
Through Scratch Programming. Computational Thinking in the STEM Disciplines, 227-251.

Malik, S., and Coldwell-Neilson, J. (2018). Gender differences in an introductory programming course: New teaching approach, students' learning outcomes, and perceptions. Education And Information Technologies, 23(6), 2453-2475.

Matopolskie Talenty (2020). https : //mapadotacji.gov.pl/projekty/762807/

Master, A., Cheryan, S., Meltzoff, A. N. (2016). Computing Whether She Belongs: Stereotypes Undermine Girls' Interest And Sense Of Belonging In Computer Science. Journal Of Educational Psychology, 108 (3), 424-437.

Master, A., Cheryan, S., Moscatelli, A., Meltzoff, A. N. (2017). Programming Experience Promotes Higher STEM Motivation Among First-Grade Girls. Journal Of Experimental Child Psychology, 160, 92-106.

Master IT (2020). http: //konkurs . aktin.pl/

Meelissen, M.R.M., Punter, R.A., Drent, M. (2014). Digitale geletterdheid van leerlingen in het tweede leerjaar van het voortgezet onderwijs: Nederlandse resultaten van ICILS-2013. University of Twente, Enschede.

MEN (2013). Dz.U.2013.199. Rozporzadzenie Ministra Edukacji Narodowej z dnia 1 lutego 2013 r. w sprawie szczegółowych zasad działania publicznych poradni psychologiczno-pedagogicznych, w tym publicznych poradni specjalistycznych (p. 7).

MEN (2019). Dz.U.2019.373. Rozporzadzenie Ministra Edukacji Narodowej z dnia 22 lutego 2019 r. w sprawie oceniania, klasyfikowania i promowania uczniów i słuchaczy w szkołach publicznych (p. 11).

MEN (2020a). Obwieszczenie Ministra Edukacji Narodowej z dnia 25 maja 2020 r. w sprawie ogłoszenia jednolitego tekstu rozporzadzenia Ministra Edukacji Narodowej i Sportu w sprawie organizacji oraz sposobu przeprowadzania konkursów, turniejów i olimpiad (p. 9).

MEN (2020b). Dz.U.2020.1280. Obwieszczenie Ministra Edukacji Narodowej z dnia 9 lipca 2020 r. w sprawie ogłoszenia jednolitego tekstu rozporządzenia Ministra Edukacji Narodowej w sprawie zasad organizacji i udzielania pomocy psychologiczno-pedagogicznej $w$ publicznych przedszkolach, szkołach i placówkach (p. 9).

Międzynarodowy Konkurs Informatyczny Bóbr (2020). https : //www . bobr .edu .pl/

Mistrzostwa Polski MindCloud (2020). https://mindcloud.pl/mistrzostwa/

Mistrzostwa w Algorytmice i Programowaniu (2020). https : //map.org.pl/

Mladenović, M., Boljat, I., and Mustapić Jogun, N. (2020). Students' attitudes towards informatics: a gender differences. INTED2020 Proceedings, 6349-6357.

Notten, N., Peter, J., Kraaykamp, G., Valkenburg, P.M. (2009). Research note: Digital divide across borders a cross-national study of adolescents' use of digital technologies. European Sociological Review, 25(5), $551-560$.

Olimpiada Informatyczna (2020). https://www.oi.edu.pl/

Olimpiada Informatyczna Juniorów (2020). https://oij .edu.pl/

Orzet Informatyczny (2020). https : //www .konkursy-delta.edu.pl/orze322-informatyczny.html

Panskyi, T., Rowinska, Z., Biedron S. (2019). Out-of-school assistance in the teaching of visual creative programming in the game-based environment - Case study: Poland. Thinking Skills And Creativity, 34, 100593.

Pechtelidis, Y., Kosma, Y., Chronaki, A. (2015). Between a rock and a hard place: Women and computer technology. Gender And Education, 27(2), 164-182.

Potyczki Algorytmiczne (2020). https ://potyczki .mimuw.edu.pl/

Program Rozwoju Talentów Informatycznych na lata 2019-2029 (2020). http://prawo.sejm.gov.pl/isap.nsf/DocDetails.xsp?id=WMP20190000571.

Program stypendialny dla uczniów szczególnie uzdolnionych - najlepsza inwestycja w człowieka (2020). https://mapadotacji.gov.pl/projekty/760826/

Programy pomocy stypendialnej dla uczniów zdolnych (2020). https://mapadotacji.gov.pl/projekty/758850/

Quadrathlon Informatyczny (2020). https://sitech.apsl.edu.pl/instytut-nauk-scislych-itechnicznych/quadrathlon/quadrathlon-2020

Rydzewska, K., Rusanowska, M., Krejtz, I., Sedek, G. (2017). Uncontrollability in the classroom: The intellectual helplessness perspective. Coping with the Lack of Control in the Social World. Routledge/Taylor \& Francis Group, New York.

Sáinz, M., Pálmen, R., García-Cuesta, S. (2012). Parental and Secondary school teachers' perceptions of ICT professionals, gender differences and their role in the choice of studies. Sex Roles, 66(3-4), 235-249.

Smith, I. (2010). Boys, Girls \& Learning Pocketbook. Teachers' Pocketbooks.

Spanos, D., Sofos, A. (2015). The Views And Attitudes Of Students Participating In: A One-To-One Laptop 
Initiative in Greece. Education And Information Technologies, 20(3), 519-535.

Stachera, H., Kijo, A., Wilińska, J. (2014). Jak pomagać uczniom rozwijać uzdolnienia informatyczne?. Ośrodek Rozwoju Edukacji, Warszawa.

Stockdale, R., Keane, T. (2016). Influencing the influencers: The role of mothers in IT career choices. Journal Of Information Technology Education: Innovations In Practice, 15, 181-194.

Sysło, M. (2011). Praca z uczniem uzdolnionym informatycznie. Wyższa Szkoła Informatyki, Warszawa.

Sysło, M. (2014). The first 25 years of computers in education in Poland: 1965-1990. Reflections on the History of Computers in Education, 266-290.

Sysło, M. (2019). Informatyka -fundamenty wdrażania. Informatyka w Edukacji. Torun, Poland.

Sysło, M., Kwiatkowska, A. (2015). Introducing a new computer science curriculum for all school levels in Poland. Lecture Notes In Computer Science, 141-154.

Tabach, M., Trgalová, J. (2019). The knowledge and skills that mathematics teachers need for ICT integration: The issue of Standards. Technology In Mathematics Teaching, 183-203.

Tømte, C., Hatlevik, O.E. (2011). Gender-differences in self-efficacy ICT related to various ICT-user profiles in Finland and Norway. How do self-efficacy, gender and ICT-user profiles relate to findings from PISA 2006. Computers \& Education, 57(1), 1416-1424.

Wiśniewski, J., Zahorska, M. (2020). Reforming education in Poland. Audacious Education Purposes, 181208.

Wolfensberger, M.V.C. (2015). Talent Development In European Higher Education. Springer, Cham.

T. Panskyi received his MS from the Lviv Polytechnic National University, Institute of Telecommunications, Radioelectronics and Electronic Engineering. Currently he is a PhD student at Lodz University of Technology, Institute of Applied Computer Science. His areas of interest are computational thinking, digital game-based learning, creative programming, ICT, data mining.

E. Korzeniewska received her PhD and Habilitation degree from Lodz University of Technology, Faculty of Electrical, Electronic, Computer and Control Engineering. Currently she holds a position as an assistant professor at Lodz University of Technology, Institute of Electrical Engineering Systems. Her areas of interest are digital game-based learning, creative programming, design thinking, algorithmics, textronics, thin electrically conductive layers, and functionalization of textile products, as well as laser technologies in the modification of surface properties of materials. 


\section{Appendix A.}

\section{The example tasks for basic level in Stage II of the InfoSukces contest.}

1. Which of the tags does not have a closing tag in HTML?
a) $<$ b $>$
b) $<$ body $>$
c) $<$ img $>$
d) everyone has

2. Phishing is:
a) macro virus
b) Trojan horse
c) phishing of personal information by impersonating a trusted person or entity, e.g. a bank
d) a virus that destroys data on a computer

3. How many question marks will the following program print?

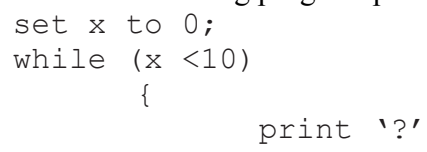
a) 10
b) 9
c) 1
d) infinitely many

4. In a spreadsheet expression $=$ SUM (A1: D3) indicates that for calculation were used:
a) 3 rows and 4 columns
b) 4 lines and 3 columns
c) 3 rows and 1 column
d) 1 row and 3 columns

5. The writing of the algorithm in a specific programming language is:
a) compilation
b) documentation
c) implementation
d) visualization

\section{Appendix B.}

The example tasks for advanced level in Stage II of the InfoSukces contest.

1. The binary addition $1+1+1$ gives:
a) 111
b) 10
c) 110
d) 11 
2. Your TV remote control got flooded with tea and some buttons stopped working. Fortunately, the + and - buttons are good for switching between channels. You have also noticed that some buttons with numbers work and the ENTER button allows you to confirm the selected channel with the help of digits (e.g. selecting channel 16 requires pressing the sequence of 3 buttons: 1 6 ENTER). Thanks to this, it is possible to minimize the number of button presses when switching between channels (of course, you can always use the + and - buttons, but with 300 channels it can be cumbersome). What is the minimum number of button presses needed to switch from channel 40 to 50, assuming that among the number buttons only buttons with numbers 4 and 5 work?
a) 10
b) 9
c) 8
d) 7

3. The value of the expression $(3 F F)_{16}-(1023)_{10}$ in the decimal system is
a) it cannot be counted
b) 0
c) 1
d) -1

4. Enter the values of variables A, B and C (real numbers).

If $\mathrm{A}>\mathrm{B}$, then swap their values with places.

If $B>C$, then swap their values with places.

If $\mathrm{A}>\mathrm{B}$, then swap their values with places.

List the values of A, B, C and complete the algorithm. will result in:
a) outputting the input numbers in unchanged order
b) outputting the input numbers in descending order
c) error, the algorithm cannot complete
d) outputting the input numbers in ascending order

5. What does the following code return?

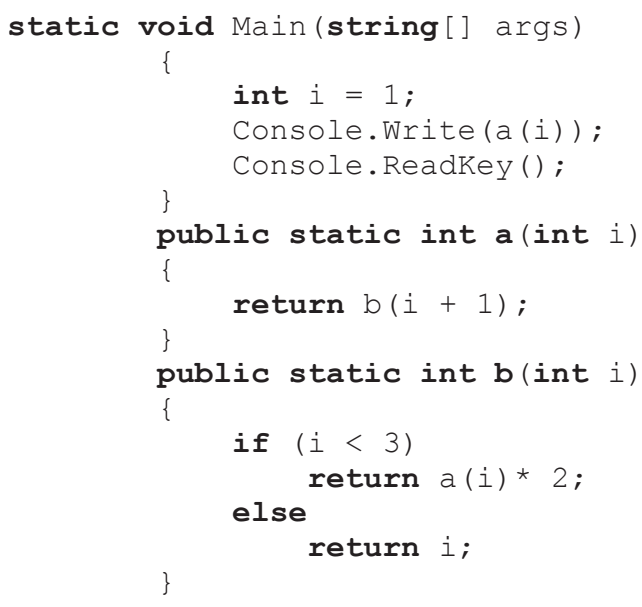
a) 1
b) 2
c) 3
d) 6 